\title{
The persistence of regional unemployment: evidence from China
}

\author{
ZHONGMIN WU \\ Canterbury Business School, University of Kent at Canterbury, Kent CT2 7PE UK \\ E-mail: Z.Wu-3@ukc.ac.uk
}

The purpose of this paper is to examine the persistence of regional unemployment and to explore the sources of this persistence. Evidence from China suggests three empirical findings. First, provincial relative unemployment is more persistent than aggregate unemployment. Second, youth unemployment is less persistent than total unemployment. Third, although the western region has the highest provincial unemployment rate, it has the lowest persistence of regional unemployment. To explore the sources of this unemployment persistence, a panel data method has been developed based on the Barro Approach and Edwards' work. The higher the share of industry output by state sector and collective sector, the more the regional unemployment persistence. The private sector is the main employment destination for jobless now and has acted to reduce unemployment persistence.

\section{INTRODUCTION}

The persistence of unemployment has been the concern of many economists since the high European unemployment of the 1980s. Among others, Blanchard and Summers (1986) explore theoretically and empirically the idea of macroeconomic hysteresis. Barro (1988) uses a time series approach to assess the extent of unemployment persistence. Jimeno and Bentolila (1998) provide a theoretical model to explain regional unemployment persistence for Spain.

Over the past two decades, China has experienced rapid economic change. The coastal areas in the east are developing more quickly than the central and western regions. Meanwhile regional unemployment in the west has been much higher than that in the east. Although this pattern has persisted for over two decades there has been little attempt to explain regional unemployment persistence in China. The purpose of this paper is to examine the persistence of regional unemployment and to explore the sources of this persistence. Section II provides evidence that regional unemployment is persistent in China. Section III investigates the sources of unemployment persistence and Section IV concludes. A panel data method has been developed based on the Barro (1988) approach and
Edwards' (2000) work. We argue that the higher the share of industry output by the state sector and collective sector, the greater the regional unemployment persistence. The private sector is the main employment destination for jobless now and has acted to reduce unemployment persistence.

\section{UNEMPLOYMENT PERSISTENCE}

This section attempts to measure the persistence of regional unemployment in China. First, the provincial unemployment rates in 1988 and 1997 are presented in a scatter graph (Fig. 1). The ranking of provinces according to their unemployment rate has remained remarkably stable over ten years. Similar graphs would also show high stability in the ranking of youth unemployment.

Figure 2 shows a cross-correlation matrix for regional patterns of provincial unemployment rates.

If correlation below 0.7 is taken as indicating substantial change, Fig. 2 suggests that the regional pattern has altered in 1992, 1993, 1997 and 1998. Compared with OECD countries (OECD, 1989), regional unemployment in China is more persistent than that in Australia and USA, 

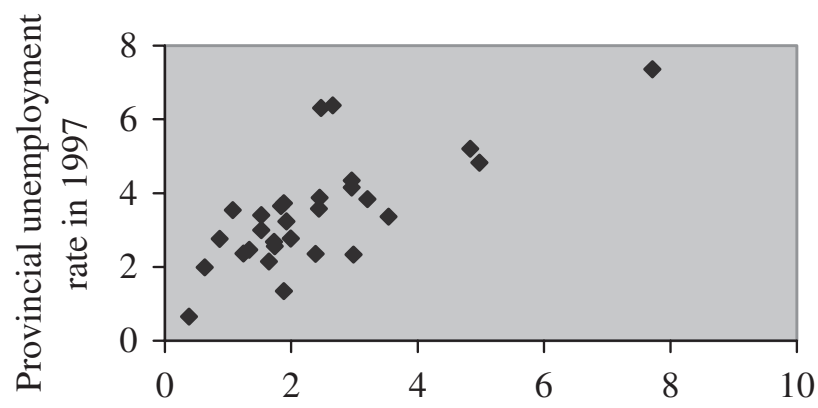

Provincial unemployment rate in 1988

Fig. 1. Provincial unemployment rate in 1988

$\left.\begin{array}{rrrrrrrrrrr}98 & 97 & 96 & 95 & 94 & 93 & 92 & 91 & 90 & 89 \\ 97 & & & & & & & & & & \\ 96 & 0.62 & & & & & & & & & \\ 95 & 0.66 & 0.96 & & & & & & & & \\ 94 & 0.67 & 0.85 & 0.94 & & & & & & & \\ 93 & 0.66 & 0.87 & 0.95 & 0.97 & & & & & & \\ 92 & 0.74 & 0.76 & 0.85 & 0.89 & 0.92 & & & & & \\ 91 & 0.62 & 0.68 & 0.78 & 0.87 & 0.90 & 0.93 & & & & \\ 90 & 0.59 & 0.73 & 0.83 & 0.90 & 0.87 & 0.84 & 0.89 & & & \\ 89 & 0.50 & 0.67 & 0.76 & 0.83 & 0.81 & 0.77 & 0.83 & 0.93 & & \\ 88 & 0.44 & 0.62 & 0.72 & 0.77 & 0.74 & 0.69 & 0.71 & 0.85 & 0.94 & \\ 0.41 & 0.61 & 0.71 & 0.75 & 0.70 & 0.63 & 0.66 & 0.83 & 0.91 & 0.94\end{array}\right)$

Fig. 2. Correlation matrix of provincial unemployment rates for 29 province cross-section data

less persistent than that in UK and Italy, and similar to that in Canada, West Germany and France.

Blanchard and Summers (1986) estimated an AR (1) process for UK and USA:

$$
\begin{gathered}
\mathrm{UK}: \quad U=\underset{(0.04)}{0.93} U(-1)+e \quad \sigma_{\mathrm{e}}=2.1 \% \\
\mathrm{USA}: \quad U=\underset{(0.04)}{0.90} U(-1)+e \quad \sigma_{\mathrm{e}}=2.0 \%
\end{gathered}
$$

In both cases, the degree of first-order serial correlation is high. Unemployment is indeed surprisingly persistent. It exhibits at best a weak tendency to return to its mean.

Similar work for China from time series 1978-1998 (national level) are given:

China (total unemployment rate) :

$$
U=0.46+0.812 U(-1)+e \quad R^{2}=0.86
$$

$$
\text { (10.5) }
$$

China (total unemployment rate) :

$$
U Y=2.38+0.732 U Y(-1)+e \quad R^{2}=0.56
$$

Numbers in parentheses are $t$-ratios.
To measure the persistence of regional unemployment, the model is developed for panel data

$$
U_{i t}=\alpha+\beta U_{i t-1}+\varepsilon_{i t}
$$

Equation 5 is estimated in TSP with panel data methodology. Ordinary Least Squares (OLS), the Fixed Effects Model and the Random Effects Model were estimated. Using Hausman's test, $R$-squared and $t$-ratios, it was found that the fixed effect model was acceptable. It performed better than the random effects model and plain OLS. Consequently, we report results of the fixed effect models in this section. The results are given in Tables 2 and 3 .

The empirical results in Tables 1,2 and 3 suggest three important findings. First, provincial unemployment is more persistent than aggregate unemployment. For both national and regional data, ordinary least squares estimators are given in Table 1. However, national data is a 20-year time series from 1979 to 1998, and regional data is panel data from 1989 to 1998 for 29 provinces. Jimeno and Bentolila (1998) argue that increased wage flexibility would, under some conditions, lead to less unemployment persistence. Since there are reasons to believe that wage flexibility is higher at the national than at the regional level, thus regional relative unemployment would tend to be more persistent than aggregate unemployment. Second, youth unemployment is less persistent than total unemployment. Youth unemployed are mainly school-leavers. They are actively searching for their first job. Adult unemployed are mainly people who have failed to keep their jobs. They find it difficult to maintain their skills and have disadvantage in learning new skills compared to youths. 'Just like physical capital, human capital is likely to depreciate in the absence of regular maintenance. Moreover, long-term unemployment may have a demoralizing effect on search behaviour, contributing to a less efficient matching process' (Roed, 1997). Third, although the western region has the highest provincial unemployment rate, it has the lowest persistence of regional unemployment. The observed fastest growing employment in the western region may explain this.

Table 1.

\begin{tabular}{lccc}
\hline & & Regional & \\
\cline { 3 - 4 } Persistence of & National & $\begin{array}{l}\text { Without } \\
\text { year dummy }\end{array}$ & $\begin{array}{c}\text { With year } \\
\text { dummy }\end{array}$ \\
\hline Unemployment & 0.812 & 0.820 & 0.842 \\
$\quad$ rate & $(10.5)$ & $(15.3)$ & $(17.4)$ \\
Youth unemployment & 0.732 & 0.793 & 0.808 \\
$\quad$ rate & $(4.76)$ & $(19.9)$ & $(21.8)$ \\
\hline
\end{tabular}

Numbers in parentheses are $t$-ratios. 
Table 2. Total unemployment equations: dependent variable = total unemployment rate

\begin{tabular}{|c|c|c|c|c|c|c|}
\hline Variable & East & Middle & West & East & Middle & West \\
\hline (Total unemployment rate) $)_{t-1}$ & 0.618 & 0.755 & 0.413 & $\begin{array}{r}0.597 \\
(587)\end{array}$ & 0.721 & 0.382 \\
\hline$R^{2}$ & $\begin{array}{r}(5.94) \\
0.814\end{array}$ & $\begin{array}{l}(10.4) \\
0.815\end{array}$ & $\begin{array}{r}(2.26) \\
0.560\end{array}$ & $\begin{array}{r}(5.8 /) \\
0.872\end{array}$ & $\begin{array}{r}(1.73) \\
0.863\end{array}$ & $\begin{array}{r}(2.70) \\
0.789\end{array}$ \\
\hline Year dummies & & & & Yes & Yes & Yes \\
\hline
\end{tabular}

Numbers in parentheses are $t$-ratios.

Table 3. Youth unemployment equations: dependent variable = youth unemployment rate

\begin{tabular}{|c|c|c|c|c|c|c|}
\hline Variable & East & Middle & West & East & Middle & West \\
\hline (Youth unemployment rate) $)_{t-1}$ & $\begin{array}{l}0.448 \\
(3.11)\end{array}$ & $\begin{array}{c}0.567 \\
(5.25)\end{array}$ & $\begin{array}{c}0.265 \\
(1.18)\end{array}$ & $\begin{array}{c}0.495 \\
(3.41)\end{array}$ & $\begin{array}{l}0.595 \\
(4.92)\end{array}$ & $\begin{array}{r}0.285 \\
(1.55)\end{array}$ \\
\hline$R^{2}$ & 0.727 & 0.760 & 0.570 & 0.791 & 0.797 & 0.756 \\
\hline Year dummies & & & & Yes & Yes & Yes \\
\hline
\end{tabular}

Numbers in parentheses are $t$-ratios.

\section{SOURCES OF PERSISTENCE}

This section explains the variation in unemployment persistence across Chinese provinces. First, some other important work is reviewed, then the sources of unemployment persistence for China are explored.

Barro Model: Barro (1988) developed the Hall (1979) model to measure the persistence of unemployment. Each unemployed person has a job-finding rate of $f$ and a jobseparation rate of $s$ per year. The unemployment rate $U_{t}$ is given by

$$
U_{t}=s+(1-s-f) U_{t-1}+\varepsilon_{t}
$$

Barro treated the term $(1-s-f)$ as a measure of unemployment persistence. He used a time series approach to estimate AR1 coefficients. The total 34 estimated AR1 coefficients were treated as proxies for regional unemployment persistence. Barro ran the weighted regression for some subset of the 34 observations.

Edwards and Edwards (2000) analysed the national unemployment persistence in Chile by considering a simple process that relates the current rate of unemployment to its lagged value and to the deviations of the rate of growth of GDP from its long-term trend:

$$
U_{t}=\alpha+\beta U_{t-1}+\gamma \times \text { GDP growth gap }+\varepsilon_{t}
$$

The degree of persistence in unemployment is given by $\beta$. In order to investigate changes in the degree of persistence, Edwards allowed for the two crucial parameters $\alpha$ and $\beta$ (which determine the natural rate of unemployment) to vary over time.

$$
\begin{aligned}
U_{t} & =\alpha_{t}+\beta_{t} U_{t-1}+\gamma \times\left(g_{t}-g_{t}^{*}\right)+\varepsilon_{t} \\
\alpha_{t} & =\alpha_{t-1}+\xi_{t} \quad \beta_{t}=\beta_{t-1}+\zeta_{t}
\end{aligned}
$$

Then they decomposed the estimated persistence parameter $\beta$ into two components:

$$
\text { Persistence } \begin{aligned}
\beta_{t}= & \gamma_{0}+\gamma_{1} \log (\text { Collective Index })_{t} \\
& +\gamma_{2} \log (\text { Protection Index })_{t}+\varepsilon_{t}
\end{aligned}
$$

Collective Index and Protection Index are indexes that measure the degree of restrictiveness and centralization of collective bargaining and union legislation and the cost of job protection legislation respectively.

Modification of the Barro and Edwards and Edwards approach: a weak point of the Barro approach is the data problem. Both his time series and cross-section data are short and he estimates them separately. To improve this method, the following procedure has been developed.

This work is based on the Barro approach, but is extended to panel data methodology and includes Okun's Law, as suggested in Edwards and Edwards. To measure regional unemployment persistence, Edwards' Equation 8 is developed for panel data:

$$
\begin{aligned}
U_{i t} & =\alpha+\beta_{i t} U_{i t-1}+\gamma \times \text { GDP growth rate }+\varepsilon_{i t} \\
i & =1,2, \cdots, 29 \quad t=1989, \cdots, 1998
\end{aligned}
$$

To explain the persistence of regional unemployment in China, the share of industry output by the State sector and Collective sector is used:

$$
\beta_{i t}=a+b X_{i t}+c Y_{i t}
$$

where $X_{i t}$ is the share of industry output by the state sector and $Y_{i t}$ is the share of industry output by the collective sector. We expect that $X_{i t}$ and $Y_{i t}$ have positive effects on regional unemployment persistence, since it is known that the private sector is the major sector absorbing the jobless, and the labour market in the private sector is much more flexible than that in state and collective sectors. 
From Equations 10 and 11

$$
\begin{aligned}
U_{i t}= & \alpha+\beta_{i t} U_{i t-1}+\gamma \times G D P \text { growth rate }+\varepsilon_{i t} \\
= & \alpha+\left(a+b X_{i t}+c Y_{i t}\right) U_{i t-1}+\gamma \times G D P \text { growth rate }+\varepsilon_{i t} \\
= & \alpha+a U_{i t-1}+b X_{i t} U_{i t-1}+c Y_{i t} U_{i t-1}+\gamma \\
& \times G D P \text { growth rate }+\varepsilon_{i t}
\end{aligned}
$$

This is a dynamic panel data model. Equation 12 can be rewritten as:

$$
\begin{aligned}
& U_{i t}-U_{i t-1}=\alpha+(a-1) U_{i t-1}+b X_{i t} U_{i t-1} \\
& \quad+c Y_{i t} U_{i t-1}+\gamma \times G D P \text { growth rate }+\varepsilon_{i t}
\end{aligned}
$$

Panel data methodology is used to estimate Equation 12a. The summary statistics and explanations of the dependent and independent variables are provided in Table 4.

The plain OLS, the Fixed Effects Model, and the Random Effects Model were estimated for Equation 12a. The results are given in Tables 5 and 6 . According to the

2 Hausman Test, LM het. Test, $R$-squared and $t$-ratios, the best model is the fixed effects model without year dummy for youth unemployment (Table 6). Youth unemployment data are more reliable in China, as they are not distorted by the exclusion of significant numbers of laid-off workers from the more familiar unemployment statistics.
The growth rate of Real Per Capita GDP has a significant negative effect on provincial unemployment both for total and youth if there is no year dummy in the model. Youth unemployment is more sensitive to GDP than total unemployment. Increasing GDP will reduce both total and youth provincial unemployment. If there are year dummy variables in the model, the GDP growth rate is no longer significant although it is still negative, as economic growth varies by year but not really by province.

The share of industry output value by state sector has a significant positive effect on youth unemployment persistence both with and without year dummy. But there is no similarly evidence on total unemployment persistence. This may be due to the distorted data problem. However, the share of industry output value by collective sector has significant positive effect on both total and youth unemployment persistence without year dummy. Again youth unemployment is more sensitive to collective size than total unemployment. Decreasing the share of the collective sector will reduce the persistence of regional unemployment. The private sector is the major sector absorbing the jobless and increasing labour market flexibility. If there are year dummy variables in the model, the collective sector is also significant for youth unemployment

Table 4. Summary statistics of dependent and independent variables

\begin{tabular}{|c|c|c|c|c|c|c|}
\hline Variable & OLS & $\mathrm{FE}$ & $\mathrm{RE}$ & OLS & $\mathrm{FE}$ & $\mathrm{RE}$ \\
\hline \multirow[t]{2}{*}{$U_{t-1}$} & -0.275 & -0.427 & -0.343 & -0.277 & -0.789 & -0.469 \\
\hline & $(-2.85)$ & $(-4.05)$ & $(-4.05)$ & $(-2.36)$ & $(-4.07)$ & $(-4.18)$ \\
\hline \multirow[t]{2}{*}{$\left(U^{*} \text { State sector }\right)_{\mathrm{t}}$} & 0.075 & -0.338 & 0.037 & 0.131 & 0.226 & 0.266 \\
\hline & $(0.93)$ & $(-2.54)$ & $(0.48)$ & $(1.01)$ & $(1.05)$ & $(2.20)$ \\
\hline \multirow[t]{2}{*}{$\left(U^{*} \text { Collective sector }\right)_{\mathrm{t}}$} & 0.343 & 0.654 & 0.416 & 0.130 & 0.586 & 0.233 \\
\hline & $(1.97)$ & $(2.63)$ & $(3.35)$ & $(0.82)$ & $(1.45)$ & $(1.23)$ \\
\hline \multirow{2}{*}{$(G D P \text { growth rate })_{\mathrm{t}}$} & -2.233 & -2.137 & -2.253 & -0.402 & -0.509 & -0.417 \\
\hline & $(-5.29)$ & $(-5.02)$ & $(-4.54)$ & $(-0.67)$ & $(-0.78)$ & $(-0.63)$ \\
\hline$R^{2}$ & 0.192 & 0.379 & 0.185 & 0.315 & 0.466 & 0.302 \\
\hline LM het. test & 54.9 & 101 & 54.6 & 55.1 & 94.6 & 63.4 \\
\hline \multicolumn{2}{|l|}{ Hausman test } & & 18.6 & & & 36.9 \\
\hline Year dummies & & & & Yes & Yes & Yes \\
\hline
\end{tabular}

\begin{tabular}{llrr}
\hline & Mean & Std Dev & Min \\
\hline Total unemployment rate (\%) & 2.876 & 1.25 & 0.350 \\
Youth unemployment rate (\%) & 9.187 & 4.45 & 7.428 \\
Share of industry output by State sector & 0.515 & 0.20 & 0.899 \\
Share of industry output by Urban Collective sector & 0.273 & 0.14 & 0.094 \\
Growth rate of real per capita GDP & 0.065 & 0.07 & 0.026 \\
\hline
\end{tabular}

Sources: NBS (1989-99), China Labour Statistical Yearbook, NBS (1989-99), China Statistical Yearbook.

Number of observations: 290 (29 provinces, 10 years).

Table 5. Total unemployment equations: panel data for 29 provinces in the 10 years 1989-1998, a total of 290 observations: dependent variable $=U_{t}-U_{t-1}$

Numbers in parentheses are $t$-ratios. 
Table 6. Youth unemployment equations: panel data for 29 provinces in the 10 years 1989-1998, a total of 290 observations: dependent variable $=U Y_{t}-U Y_{t-1}$

\begin{tabular}{|c|c|c|c|c|c|c|}
\hline Variable & OLS & FE & $\mathrm{RE}$ & OLS & FE & RE \\
\hline \multirow[t]{2}{*}{$U Y_{t-1}$} & -0.436 & -0.887 & -0.615 & -0.432 & -1.076 & -0.730 \\
\hline & $(-4.08)$ & $(-4.05)$ & $(-7.15)$ & $(-3.12)$ & $(-5.14)$ & $(-5.04)$ \\
\hline \multirow[t]{2}{*}{$\left(U Y^{*} \text { State sector }\right)_{t}$} & 0.231 & 0.218 & 0.290 & 0.268 & 0.407 & 0.472 \\
\hline & $(2.52)$ & $(1.75)$ & (3.09) & $(1.79)$ & $(1.92)$ & $(3.01)$ \\
\hline \multirow[t]{2}{*}{$\left(U Y^{*} \text { Collective sector }\right)_{t}$} & 0.442 & 0.712 & 0.495 & 0.328 & 0.959 & 0.487 \\
\hline & $(2.39)$ & $(2.68)$ & $(3.39)$ & $(1.76)$ & $(2.22)$ & $(2.02)$ \\
\hline \multirow[t]{2}{*}{$(G D P \text { growth rate })_{t}$} & -6.372 & -5.121 & -6.178 & -1.664 & -0.872 & -1.727 \\
\hline & $(-3.98)$ & $(-3.52)$ & $(-3.41)$ & $(-0.58)$ & $(-0.39)$ & $(-0.71)$ \\
\hline$R^{2}$ & 0.202 & 0.404 & 0.195 & 0.289 & 0.476 & 0.271 \\
\hline LM het. test & 8.59 & 39.8 & 5.37 & 18.7 & 56 & 14.7 \\
\hline Hausman test & & & 6.53 & & & 7.64 \\
\hline Year dummies & & & & Yes & Yes & Yes \\
\hline
\end{tabular}

Numbers in parentheses are $t$-ratios.

persistence, but it is no longer significant for total unemployment persistence.

\section{CONCLUSIONS}

This paper examines unemployment persistence in China. Studies have focused on differences between youth and total, national level and regional level in unemployment persistence. The empirical results from China suggest three important findings. First, provincial unemployment is more persistent than aggregate unemployment. Second, youth unemployment is less persistent than total unemployment. Third, although the western region has the highest provincial unemployment rate, it has the lowest persistence of regional unemployment.

Based on the Barro Approach and Edwards' work, a panel data method has been developed to explore the sources of unemployment persistence. Barro's work has a weak point on data. Both his time series and cross-section data are short and he estimates them separately. Edwards and Edwards focus only on time series data. Using two important pieces of work, a panel data approach has been developed to deal with unemployment persistence.

The observed high persistence of regional relative unemployment in China results not only from the high output share by state sector, but also from the high output share by the collective sector. The higher the share of industry output by state sector and collective sector, the more the regional unemployment persistence. The private sector is the main employment destination for the jobless now, and the growth of this sector has acted to reduce unemployment persistence in China.

\section{REFERENCES}

Barro, R. J. (1988) The persistence of unemployment, American Economic Review, 78(2), 32-7.

Blanchard, O. and Summers, L. (1986) Hysteresis and the European unemployment problem, NBER Macroeconomics Annual, Cambridge, MA, pp. 15-78.

Edwards, S. and Edwards, A. C. (2000) Economic reforms and labour markets: policy issues and lessons from Chile, Economic Policy: A European Forum, 0(30), 181-222.

$\mathrm{Gu}$, E. X. (1999) From permanent employment to massive layoffs, Economy and Society, 28, 281-99.

Hall, R. E. (1979) A theory of the natural unemployment rate and the duration of employment, Journal of Monetary Economics, 5, 153-69.

Jimeno, J. F. and Bentolila, S. (1998) Regional unemployment persistence (Spain, 1976-1994), Labour Economics, 5(1), $25-51$.

National Bureau of Statistics, P. R. of China (1989-1999) China Statistical Yearbook, China Statistical Publishing House.

National Bureau of Statistics and Ministry of Labour, P. R. of China (1989-1999) China Labour Statistical Yearbook, China Statistical Publishing House.

OECD (1989) Regional Unemployment in OECD Countries, Employment Outlook.

Roed, K. (1997) Hysteresis in unemployment, Journal of Economic Surveys, 11, 389-418.

Wu, Z. (2001) Regional unemployment, rural-to-urban migration and the economic reforms of China. Department of Economics, University of Southampton, $\mathrm{PhD}$ thesis. 


\section{AUTHOR QUERIES}

\section{JOURNAL ID: RAEF-100804}

QUERY NUMBER

Please check West Germany is OK?

Please check LM het. is OK?

Reference not cited in text. Please check

Reference not cited in text. Please check 